Review

\title{
Knowledge to Predict Pathogens: Legionella pneumophila Lifecycle Critical Review Part I Uptake into Host Cells
}

\author{
Alexis L. Mraz ${ }^{1}$ and Mark H. Weir ${ }^{1,2, *}$ \\ 1 Division of Environmental Health Sciences, College of Public Health, The Ohio State University, \\ Columbus, OH 43210, USA; alexis.l.mraz@gmail.com \\ 2 Risk Modeling Division, Applied Research Center, NSF International, Ann Arbor, MI 48105, USA \\ * Correspondence: weirmarkh@gmail.com; Tel.: +1-614-292-4066
}

Received: 16 December 2017; Accepted: 29 January 2018; Published: 31 January 2018

\begin{abstract}
Legionella pneumophila (L. pneumophila) is an infectious disease agent of increasing concern due to its ability to cause Legionnaires' Disease, a severe community pneumonia, and the difficulty in controlling it within water systems. L. pneumophila thrives within the biofilm of premise plumbing systems, utilizing protozoan hosts for protection from disinfectants and other environmental stressors. While there is a great deal of information regarding how L. pneumophila interacts with protozoa and human macrophages (host for human infection), the ability to use this data in a model to attempt to predict a concentration of L. pneumophila in a water system is not known. The lifecycle of L. pneumophila within host cells involves three processes: uptake, growth, and egression from the host cell. The complexity of these three processes would risk conflation of the concepts; therefore, this review details the available information regarding how L. pneumophila invades host cells (uptake) within the context of data needed to model this process, while a second review will focus on growth and egression. The overall intent of both reviews is to detail how the steps in L. pneumophila's lifecycle in drinking water systems affect human infectivity, as opposed to detailing just its growth and persistence in drinking water systems.
\end{abstract}

Keywords: Legionella pneumophila; legionellosis; uptake process; drinking water; review

\section{Introduction}

\subsection{Rationale: Human Health Impacts and Level of Concern}

Legionellosis, a set of two respiratory diseases caused by the inhalation of Legionella bacteria, incorporates Pontiac Fever and Legionnaires' disease (LD), a severe form of pneumonia. Pontiac Fever, a self-limiting flu-like illness, is characterized by a respiratory infection lasting two to five days without the development of a pneumonia [1]. Those affected may experience fever, chills, malaise, myalgia, headache, cough, or chest pain, after a typical incubation period of one to two days [1]. The disease was first discovered in Pontiac, Michigan, USA in 1968. At the time of occurrence, the etiological agent of the disease was unable to be identified, with the source of the outbreak surmised to be a toxin due to the speed of symptom onset and lack of etiological agent [2]. It was not until an outbreak of community pneumonia in 1976 that LD was investigated, and Legionella pneumophila (L. pneumophila) was identified as the causative agent [1,2]. As the etiological agent was discovered because of an outbreakat an American Legion convention in Philadelphia, LD is thusly named. During this outbreak, 29 of the 182 cases were fatal, and a gram-negative bacillus was isolated and determined to be the cause. It was later determined that the same bacterium was the etiological agent of Pontiac Fever [3-5].

LD has similar symptoms to Pontiac Fever with the addition of a severe pneumonia. Though Legionella may cause sub-clinical infections, more serious cases of LD can cause long-term symptoms 
including easy fatigue, shortness of breath, muscle or joint pain, productive cough, and memory loss [6-8]. LD can have an incubation time ranging from two days to two weeks, depending on the patient's immunocompetence and if antibiotic therapy was administered [8,9]. There is an increased risk of legionellosis in those with a non-municipal water supply, recent residential plumbing repair, electric water heaters (as opposed to gas), smokers, and those who work more than $40 \mathrm{~h}$ a week [10-12]. The elderly, males, smokers, those with nosocomial infections, renal disease or immunodeficiency have increased risk of succumbing to the pneumonia [10,13].

Legionellosis is the most common cause of all reported water-associated diseases in the US, and its incidence is steadily increasing $[14,15]$. The US averages $10,000-15,000$ cases per year, and L. pneumophila was the cause of half of all reported waterborne disease outbreaks in 2005-2006 [16-18]. Due to the prevalence and seriousness of LD, L. pneumophila was added to the United States Waterborne Disease Outbreak Surveillance System in 2001 and the US Environmental Protection Agency (EPA) Candidate Contaminant List (CLL) as an important pathogen. By 2006, Legionella spp. was the third most common etiological agent of waterborne disease reported in the United States $[19,20]$. The majority of cases are community acquired with an unknown source of infection, though it is difficult to accurately report cases associated with travel, due to varying incubation times, illness occurring far from the infection source, and the possibility that symptoms do not require medical attention [21]. Legionellosis can only be spread when the bacterium is aerosolized and respired [22,23]. Sources of legionellosis outbreaks include contaminated hospital bathrooms [24], grocery-store mist machines [25], sprinklers [26], cooling towers [27-29], heating ventilation air conditioning systems (HVAC) [30,31], humidifiers [32], large warm water systems [33], whirlpools [21,34], pools [21] and dental office equipment $[35,36]$.

\subsection{Microbiology of Legionella spp.}

Legionella spp. describes a gram-negative bacillus bacterium. The genus is widespread in nature, common to fresh surface water, thermal water, and drinking water environments and has been found regularly in soil samples [37-39]. L. pneumophila thrive in temperatures $20-50{ }^{\circ} \mathrm{C}$ with little to no growth over $50{ }^{\circ} \mathrm{C}$, but have been isolated from hot water with temperatures as high as $66{ }^{\circ} \mathrm{C}[40,41]$. When temperatures reach $70^{\circ} \mathrm{C}$, the bacteria are killed almost instantly [42]. L. pneumophila has been shown to be tolerant to sodium chloride solutions up to $1.5 \%$ laboratory experiments and isolated in amoeba co-cultures in natural environments of up to $3 \%$ sodium chloride $[43,44]$. The bacterium has an ideal $\mathrm{pH}$ of 6.0-8.0. L. pneumophila is tolerant of low-nutrient environments but does require iron to survive and thrive $[45,46]$. In harsh environments, the bacteria can enter a viable but non-culturable (VBNC), state in which it will not replicate, but can be resuscitated in more friendly conditions [47].

The bacteria are facultative intracellular organism that can replicate freely within host cells and utilize the host for protection from environmental stressors. The most common host cells are predating protozoa such as amoeba. Legionella that have passed through protozoan hosts are more infective to mammalian macrophages [48]. Horizontal gene transfer between the bacteria and the host cell is at least partially responsible for this increase in infectivity. Over the course of its evolution, Legionella has not only acquired genes from eukaryotic host cells, but also upregulates those genes in the stationary phase of growth [49]. Legionella has unique lifecycle traits such as its ability to: attract host cells; utilize multiple pathways of infectivity on the same host cell or different host cells as required; and prevent fusion of the lysozyme to the phagosome to survive in the host. The genes and gene complexes responsible for these unique features have been largely identified. Knockdown experiments have been performed to inform the effect of particular genes on the lifecycle of Legionella however, with the exception of Bodet et al., an understanding of how environmental stressors affect these genes and in turn Legionella's lifecycle is lacking [50]. 


\subsection{Epidemiology of Legionellosis}

There are at least 51 species of Legionella and over 60 serogroups. Of these, 18 species have been shown to be pathogenic with the most common cause of legionellosis being L. pneumophila [10,51-53]. In the US, L. pneumophila serogroup 1 is responsible for $84.2 \%$ of cases and serogroups $2-13$ are responsible for $7.4 \%$. Legionella longbeachae (L. longbeachae) is responsible for 3.9\% of cases and Legionella bozemanii $2.4 \%$ of cases. These case contributions are similar in Europe but change significantly in Australia and New Zealand, where L. pneumophila serogroup 1 is responsible for $45.7 \%$ of cases, and L. longbeachae $30.4 \%$ of cases [52]. L. pneumophila is more commonly found in water, where L. longbeachae is more common in soil and associated with gardening and potting soil [54]. L. longbeachae has been shown to have enzyme systems that may assist in the degradation of plant material, possibly explaining its soil harbor [55]. Epidemiological patterns of legionellosis differ in these regions too; studies have shown that more than $50 \%$ of confirmed cases in New Zealand and Australia were a result of contact with compost [56,57].

\subsection{Objectives of this Review Article}

Legionella spp. are ubiquitous in aquatic environments with protozoan hosts [58]. The bacteria engage in a symbiotic relationship with protozoa within biofilms where Legionella is present, such as premise plumbing, and in large distribution systems [16,59-61]. It is estimated that $95 \%$ of the bacterial biomass in drinking water are found in biofilms on the interior of distribution systems [62]. When temperature or flow rate change, the biofilms can slough off the pipes, releasing Legionella and allowing for it to be aerosolized when leaving a showerhead, faucet, or plumbing fixture [63]. Outbreaks of legionellosis are still common due to the difficulty in treating these particular bacteria within the water system. It is an unfortunate incident that alveolar macrophages behave in a nearly identical fashion to the natural hosts of L. pneumophila, thus making the bacteria easily capable of human infection. Therefore, L. pneumophila infections in humans are incidental, since the alveolar macrophages are the secondary hosts. Lau and Ashbolt [64] developed a critical review on the relationship between amoeba and L. pneumophila in water systems. However, this leaves a remaining area of knowledge that needs to be examined: the data requirements to model this relationship between amoeba and L. pneumophila. More important is the need to model the kinetics of infection of alveolar macrophages exposed to L. pneumomophila, thus allowing for a more significant understanding of the realistic health risks from L. pneumophila. Additionally, for a complete picture of distribution system risks, the uptake, growth and egression to infect other cells should be modeled. Other review articles discuss health effects, pathology, treatment, transmission, etiology, epidemiology, and infectivity of L. pneumophila $[9,20,22,23,65-69]$. Reviews that discuss growth and survival of Legionella either depend on a laboratory-based models, differing significantly from the biofilm environment, or the article focuses on some particular pathway, proteins, or genetics that affect Legionella's lifecycle. However, they do not focus on all of these aspects in one article [46,68,70-75].

There has been no critical review of how this data can be used in a model for these uptake processes. In the case of L. pneumophila modeling, these processes and how the genes regulate these processes is a vital portion of modeling a likely concentration in the drinking water systems. Another gap in reviewing the genomic mechanisms of infection in host cells exists, as will become clearer later in the review. These genomic mechanisms are vital to the lifecycle and pathogenesis of L. pneumophila. Additionally, since the processes of infection in amoeba and human alveolar macrophages are very similar, this is a rare opportunity to develop a set of models to predict both engineering impacts by predicting concentrations of L. pneumophila in water systems and tie this directly with environmental health impacts on the kinetics of growth in alveolar macrophages. Not all data are conducive to modeling; therefore, this review outlines those gaps in the data that preclude use in modeling. As we will see develop in this review, a challenge in understanding L. pneumophila is that its characteristics typically considered within the purview of biomedical research are vital in modeling its health risk potential and control in water systems. This is not wholly unique to L. pneumophila; however, 
attempting to control it without understanding how to model its lifecycle in conjunction with human infectivity risks has the potential to have serious and long-term negative control implications.

This review focuses on the information needed to model the uptake of Legionella into host cells, emphasizing the physiological and genetic pathways, and processes, with an emphasis on L. pneumophila and Acanthamoeba considering their prevalence, and macrophages considering their requirement for human infectivity. This will allow for: (1) a complete picture of the lifecycle of L. pneumophila in water systems, (2) movement towards predictive modeling of L. pneumophila concentration, (3) prediction of L. pneumophila blooms in water systems and (4) improved dose response knowledge in alveolar macrophages in humans.

\section{Materials and Methods}

\section{Literature Review Method}

To determine the mechanisms, proteins, and genes involved in the uptake of Legionella to the host cell, an exhaustive literature review was conducted. Google Scholar, PubMed, Web of Science, Bioline International, and PLOS ONE were searched using the terms: "((Legionella) OR (Legionella pneumophila) OR (L. pneumophila) OR (Legionella longbeachae) OR (L. longbeachae) OR (Legionella bozemanii) OR (L. bozemanii)) AND ((Human Health Impacts) OR (Symptoms) OR (Infectivity) OR (Uptake) OR (Host Interaction) OR (Genetic Knockout) OR (Disinfection) OR (Acanthamoeba) OR (Acanthamoeba polyphaga) OR (Acanthamoeba castellanii) OR (A. polyphaga) OR (A. castellanii) OR (Premise Plumbing) OR (Biofilms))." Relevant citations were forward and reverse citation searched and imported into a Zotero library (https:/ / www.zotero.org/alexismraz/items/). Over 1500 papers were reviewed for relevance and 177 papers were included in this review. In order to be included in the review, papers needed to inform L. pneumophila's ability to invade an amoeba or human alveolar macrophage and come from a reputable, peer-reviewed journal. In order for data to be included in this review, the study must have sufficient data points, be validated, and inform L. pnuemophila's ability to invade host cells.

\section{Results}

\subsection{Legionella pneumophila Life Cycle}

L. pneumophila has evolved alongside predatory eukaryotes, which are phagocytes, cells that predate using some form of phagocytosis. Therefore, L. pneumophila has adapted specialized communication with a variety of phagocyte to invade the host [76,77]. As opposed to other bacteria that are predated upon as a sole mechanism of uptake into amoeba, L. pneumophila can attract an amoeba and initiate its own uptake as part of its lifecycle. This specialization causes L. pneumophila to have less competition with other bacteria common to its environment, such as Escherichia coli, Aeromonas hydrophilia, Flavobacterium breve, and Pseudomonas aeruginosa [78]. L. pneumophila is known to invade host cells in a variety of forms including traditional phagocytosis, coiling phagocytosis, and pinocytosis, utilizing multiple receptor-mediated pathways. Not only will L. pneumophila utilize different methods to infect different species of host, in many cases, the bacteria are capable of utilizing more than one method of invasion on the same host cell [76-78].

Phagocytosis, a key to the lifecycle of L. pneumophila, is also its pathogenesis. A critical portion of the pathogenesis process is the genes, and gene complexes L. pneumophila uses to secrete morphological structures (e.g., pili) or reactive proteins. For example, the Dot/Icm complex associated with the flagella secretes a Type IV protein that deactivates the capsase-1 response in alveolar macrophages to prevent the destruction of L. pneumophila after infection [79]. In the case of uptake, pilE allows for the secretion of pilin protein, which, in turn, produces the long pili and allows for binding and uptake to the host cell [80]. Amoeba and alveolar macrophages are different in rates of reaction to these processes; additionally, further complicating the matter, murine macrophages do not respond the same as human macrophages [81]. 
L. pneumophila can utilize either traditional or coiling phagocytosis to invade protozoan or macrophage host cells. Coiling phagocytosis is a rare form of phagocytosis, occurring less than $10 \%$ of the time, resulting in the bacteria internalized within the host in a membrane-bound vacuole that does not fuse with lysosomes [81-84]. The complement receptor 3 (CR3) is responsible in part for the mediation of coiling phagocytosis and persists in the phagosomal membrane [85]. CR3 is also responsible for L. pneumophila's attachment to the surface of macrophages [86].

The outer membrane proteins and lipopolysaccharide (LPS) structures play an important role in adhesion and/or uptake of L. pneumophila by protozoa. L. pneumophila LPS can access classical pathways for entering cells, utilizing antibody-antigen complexes, as described above. In humans, the activation of the classical pathway can be explained by mediation by antibodies of the IgM class present in the normal human serum (NHS) [87]. However, L. pneumophila LPS is also able to enter cells (both amoeba and macrophages) via the alternate pathway if the antibodies needed to activate the classical pathway are not present [88]. The complement component (C3) covalently binds to the major outer membrane protein (MOMP) of L. pneumophila via the alternate pathway of complement activation. C3 acts as a ligand for complement receptors CR1 and CR3, which mediate phagocytosis of L. pneumophila [89].

L. pneumophila relies on a 24-kDa macrophage infectivity proteniator (Mip) protein to efficiently infect both mammalian phagocytic cells and protozoan cells [90,91]. This protein is coded for by the mip gene and is thought to be conserved throughout the Legionella genus [92-94]. The Mip sequence from 35 Legionella species was conserved at the amino acid level $82 \%$ to $99 \%$ [94]. Mip exhibits a peptidylprolyl cis/trans isomerase (PPIase) activity and belongs to the enzyme family of FK506-binding proteins (FKBP), also seen in Chlamydia trachomatis and Trypanosoma cruzi [95-97]. Amino acids involved in PPIase activity were found to be totally conserved [94]. When the protein is transported through the cytoplasmic membrane, the N-terminal signal sequence is cleaved off, and the protein is found on the surface of the L. pneumophila cell, allowing for its infectivity role $[98,99]$.

It has been shown that, for L. pneumophila to have its full virulence in higher organisms, such as guinea pigs, both the full-length Mip protein and PPIase activity are necessary [100]. While the Mip protein is important for invasion and establishment within human macrophages and protozoa, it is not necessary for intracellular replication. The Mip protein is repressed directly after the invasion of a monocytic human cell and regains activity after $24 \mathrm{~h}$ of intracellular replication. Regaining Mip activity allows for the bacteria to be infective again after replication [101]. The mip gene is therefore an important virulence indicator.

L. pneumophila was shown to require actin polymerization and intact microtubule cytoskeleton to invade HeLa cells effectively [102]. Similar results were shown in Acanthamoeba castellanii (A. castellanii) and Vermamoeba vermiformis (V. vermiformis) by utilizing cytochalasin D, a microfilament disrupter. However, cytochalasin D did not affect the uptake of L. pneumophila by Acanthamoeba polyphaga (A. polyphaga) $[48,76,103]$. This further provides evidence that L. pneumophila is capable of utilizing various and sometimes redundant pathways to infect host cells.

The $N$-acetyl-D-galactosamin (Gal/GalNAc) lectin receptor pathway and galactose (gal) are utilized by L. pneumophila to invade $V$. vermiformis. It is shown that adding gal or GalNAc to an $V$. vermiformis culture will significantly impair L. pneumophila's ability to invade the host cell [77]. It is believed that $V$. vermiformis relies on this pathway heavily, if not exclusively for receptor-mediated pinocytosis of L. pneumophila, whereas other protozoa, such as A. castellanii and A. polyphaga, utilize multiple pathways for L. pneumophila uptake [86,104].

It is uncertain what ligand from L. pneumophila activates the Gal/GalNAc lectin receptor pathway, but it has been speculated that it is one of the competence and adherence-associated pili (CAP) [105]. CAP is one of two distinct pili on the surface of L. pneumophila. It is a Type IV pili involved in adherence to protozoan and mammalian cells [80]. However, the CAP is not exclusively responsible for this attachment. In protozoa, the CAP communicates with the lectin protozoan receptor [84]. This attachment is not strong over the long term, necessitating the rapid uptake processes seen in the lectin 
pathway [82,86]. There is redundancy in the genes responsible for pili production in L. pneumophila, pilD and pilE are both responsible for pre-pilin peptidase and result in the expression of Type IV pili $[106,107]$.

L. pneumophila has high uptake rates in Acanthamoeba, a genus of amoeba commonly found in freshwater and known as a common host to the bacteria. A. polyphaga has an uptake rate of $73-98 \%$ of viable L. pneumophila cells, while A. castellanii has an uptake rate of $96-100 \%$ of viable cells [108]. These rates may be partially explained by the self-induced uptake of the bacterium into the host cell. A. castellanii phagocytizes L. pneumophila through a receptor-mediated system, utilizing the mannose-associated mannose receptor or mannose-binding lectin (MBL) [76]. L. pneumophila does not use the MBL solely for protozoan entry; it is also able to activate the MBL for quick entry to pulmonary macrophages in mammals. Interestingly, the MBL is the same receptor that $A$. castellanii uses to bind to the corneal epithelium, causing ocular infections [76]. L. pneumophila has a high affinity for the $\alpha 1-3 \mathrm{~d}$-mannobiose-binding site of the mannose receptor from $A$. castellanii, allowing for efficient uptake by the protozoa [76]. L. pneumophila has a slightly lower affinity for the d-mannose-binding receptor in A. castellanii [109]. This specificity, while known for A. castellanii, is most likely inconsistent among the entire Acanthamoeba genus. L. pneumophila will utilize predominately different pathways when infecting another genus of protozoa.

The differences between uptake of L. pneumophila into amoeba and mammalian macrophages are more pronounced than the change in uptake efficiency in varying species of Acanthamoeba. Certain genetic knockdowns, such as rpoS and let $A$ can be avirulent in protozoan hosts like $A$. castellanii, but completely unaffected in human-derived macrophages such as HL60 and THP-1 [110,111]. Furthermore, L. pneumophila can only use the Gal/GalNAc pathway, described above to invade protozoan host cells, whereas it can only use the alternate complement receptor pathways and MOMP to invade macrophage [112]. The redundancy of uptake mechanisms and the genetics involved in these mechanisms allows L. pneumophila for flexibility in infecting a variety of host cells. L. pneumophila even gains an advantage in passing through a protozoan host prior to infect a mammalian macrophage [113].

L. pneumophila that has been grown in A. castellanii culture is phenotypically different from L. pneumophila grown in standard media. Amoeba grown L. pneumophila cells were more invasive than media-grown L. pneumophila cells, 100-fold more invasive for epithelial cells and 10-fold for macrophages and amoeba [113]. The amoeba grown bacteria expressed new proteins that may be responsible for the phenotypic differences amongst the stains [113]. Studies have shown that L. pneumophila can horizontally transfer genes to and from host cells [49,114], a possible reason for increased infectivity after passage through a host-cell. However, this increase can also be a byproduct of the host cell acting as a unicellular incubator or "biological gym"; therefore, the produced bacteria are more phenotypically complete allowing for optimal infectivity [40].

\subsection{Effects of Engineered System Stressors on L. pneumophila}

There has been a variety of water treatment options tested to eradicate L. pneumophila in water distribution systems including: oxidizing agents such as chlorine, monochloramine, chlorine dioxide, bromine, iodine, ozone, hydrogen peroxide, ultraviolet (UV) radiation, heat, halogenated hydantoins, silver and copper ions, non-oxidizing agents such as aldehydes, amines, heterocyclic ketones, guanidines, thiocyanates, organo-tin compounds, halogenated amides, halogenated glycols, thiocarbamates, and heat [72,115]. While chlorine is commonly used and known to be effective, the continuous and rising number of legionellosis outbreaks causes concern that chlorine is not effective enough in removing L. pneumophila from water distribution systems [116-118]. Considering the bacteria's ability to grow within and use biofilms as protection from chlorination, complete eradication cannot be achieved without elevated water temperatures $\left(>60^{\circ} \mathrm{C}\right)[119]$.

Chlorine exists as hypochlorous acid in water in either its neutral form of $\mathrm{HOCl}$ or as hypochlorite ion, $\mathrm{OCl}^{-}$in environments where $\mathrm{pH}>$ 7.6. The term "free chlorine" refers to $\mathrm{HOCl}$ and $\mathrm{OCl}^{-}$, though $\mathrm{HOCl}$ is known to be more biocidal. Free chlorine inactivates bacteria by adversely affecting their respiratory and transport activities, causing deleterious effects on bacterial membranes, and causing 
direct oxidative damage to proteins and nucleotide bases [47,120]. Free-living L. pneumophila were killed within $3 \mathrm{~min}$ of being exposed to an aqueous solution of $2 \mathrm{mg} / \mathrm{L}$ of chlorine, whereas L. pneumophila living within biofilms were much more difficult to treat utilizing chlorine [121]. Well-developed biofilms, those 1-2 months old, were able to protect L. pneumophila even when exposed to free chlorine at $50 \mathrm{mg} / \mathrm{L}$ for $1 \mathrm{~h}$, a concentration much higher than the $5 \mathrm{mg} / \mathrm{L}$ recommended by the European Working Group for Legionella Infections [122,123]. The bacteria were able to survive treatment and continue to grow. Newer biofilms, developed in the past $72 \mathrm{~h}$, were unable to protect the bacteria to the same extent, but the treatment was not effective in eradicating L. pneumophila from the water distribution system. While no viable colonies were recovered immediately after treatment, colonies began growing again the next day [124].

The event of L. pneumophila being viable but non-culturable (VBNC) is fairly common during water treatment processes and has been documented after chlorination or other high levels of oxidative or physical stress, such as ultraviolet radiation and heat, by multiple studies [47,125-127]. It has been theorized that the bacteria become VBNC either because the cell membrane is not permeable at low chlorine levels, and the cells are stressed or injured during treatment rather than inactivated. Or the membrane is permeabilized early, and the hole allows ethidium monoazide bromide to enter the cell and prevent reproduction, but the polymerase chain reaction (PCR) signal is not always reduced [47]. Both heat and chlorination can result in damage to the cell membrane, causing the cell to become VBNC. Interestingly, this affect is mitigated if L. pneumophila is in a starvation state, possibly due to the induction of proteins that cross-protect against other stressors [128]. The occurrence of VBNC L. pneumophila in water distribution systems may lead to false confidence that the bacteria have been eradicated from the system if presence is determined by a culture method. In other species of bacteria, it has been shown that gene expression can be altered in the VBNC state, typically showing gene supression [129]. However, it has been shown that VBNC cells retain intact genetic material and there are no genetic knockdowns during the VBNC state $[130,131]$. L. pneumophila are able to produce virulence proteins, including the Mip protein when VBNC [132]. Furthermore, VBNC L. pneumophila have been shown to infect amoeba and become culturable again $[126,133,134]$. There is the possibility that VBNC are still infectious to human macrophages, thereby still presenting a public health risk $[122,135,136]$.

Chlorine neutralization can allow for greater persistence of L. pneumophila in the biofilm, accelerate the development of the microbial community, and reduce the susceptibility of disinfection in the future [137]. Therefore, it is important with regards to L. pneumophila, to ensure that premise plumbing systems do not go through regular periods of chlorine neutralization. Considering the decay of residual chlorine in large premise plumbing systems, these buildings are more likely to have sections of chlorine neutralization, which may also explain further why they are more at risk for a legionellosis outbreak [136].

It is possible that L. pneumophila are utilizing host cells that are resistant to chlorine to grow and thrive, or that chlorine is inefficient at penetrating the biofilm and therefore is not reaching the bacteria $[122,138]$. When chlorine can reach the bacteria, it is capable of altering gene expression. A 2011 study performed on free living L. pneumophila showed that non-lethal levels of chlorine caused differential expression of 391 L. pneumophila genes. In general, the chlorine treatment induced genes related to the stress response while repressing genes related to virulence [50]. However, it is unclear if chlorine can induce permanent changes to the bacteria, such as genetic knockdowns, a key to reduced uptake and infectivity. Furthermore, genetic expression studies have only been performed in free living bacteria, and not those within the biofilm.

To treat L. pneumophila in premise plumbing systems, it is necessary to penetrate the biofilm. Some studies have effectively used shock hyperchlorination, (short period of elevated chlorine dose between $20-50 \mathrm{mg} / \mathrm{L}$ ), to treat L. pneumophila in premise plumbing systems. However, maintaining high levels of chlorine in the water system can have both human health and structural effects $[119,135]$. Chlorine can be corrosive to the pipes, and its byproducts can cause adverse health effects for humans and the environment. 
The negative side effects of chlorine as a disinfectant lead to the use of monochloramine [139]. Monochloramine $\left(\mathrm{NH}_{2} \mathrm{Cl}\right)$, a derivative of ammonia, has been shown to be more effective than free chlorine as a residual disinfectant. Hospitals using free chlorine had an odds ratio of 10.2 of an LD outbreak in comparison to those using monochloramine [140]. It has been suggested that monochloramine is more effective in penetrating the biofilm than chlorine [141,142]. However, monochloramine showed similar issues to chlorine; while it was able to suppress L. pneumophila, it proved incapable of eradicating the bacteria from the system, and ineffective eradication could lead to monochloramine resistance [143-145]. It is currently unknown if monochloramine induces genetic mutations in L. pneumophila.

Bromine and iodine have both been effective in disinfecting swimming pools and cooling water. However, bromine is not recommended for potable drinking water, and there is controversy surrounding safe levels of consumption over an extended period with iodine [120,146]. While both are oxidizing agents similar to chlorine, neither is as effective as chlorine at inactivating L. pneumophila. Iodine was particularly inept at killing L. pneumophila within a biofilm $[108,147,148]$. Currently, there is no information available as to whether or not bromine or iodine cause genetic mutations within L. pneumophila.

Ozone can effectively inactivate bacteria by damaging DNA in both the gaseous and dissolved states $[149,150]$. Ozone is more effective than chlorine is controlling L. pneumophila; however, due to its quick dissipation and inability to be used as residual treatment, another form a treatment is required in conjunction with ozone to treat bacteria within biofilms in premise plumbing [151,152]. Ozone is known to damage DNA, but it is unclear if it causes specific and consistent knockdowns or other mutations in L. pneumophila.

Temperature may be the most effective means of controlling L. pneumophila in premise plumbing systems. It is recommended that recirculating hot water leaves the heater at least $60^{\circ} \mathrm{C}$ and remains at $50^{\circ} \mathrm{C}$ throughout the system. Hot water should reach the tap in a maximum of $1 \mathrm{~min}$ and be a minimum of $50{ }^{\circ} \mathrm{C}$ [153]. Maintaining hot water systems over $50{ }^{\circ} \mathrm{C}$ throughout the entirety of the premise plumbing is challenging from both an energy use and a hazard standpoint. Water stagnates for up to $23 \mathrm{~h}$ a day within buildings, leading to vast temperature fluctuations [154]. Furthermore, maintaining high water temperatures from the heater to the tap can be costly, particularly if the premise plumbing system is large [154]. Additionally, facilities with large premise plumbing systems are concerned with the risk of scalding, specifically healthcare facilities who may have patients with decreased ambulatory abilities and other health concerns, such as dementia, which may not allow them to recognize the water temperature or move from hot water in a timely manner. Maintaining temperatures high enough to retard the growth of or kill L. pneumophila could prove hazardous to the population [155]. Intermittent "super heat" flushing, maintaining the water in the system at $70^{\circ} \mathrm{C}$, and flushing the taps for $30 \mathrm{~min}$ has shown to be effective in controlling legionellosis outbreaks [156,157]. However, the logistics of "super heat" flushing may be prohibitive to many facilities.

\subsection{Engineered System Stressors within a Biofilm}

L. pneumophila is common to biofilms in premise plumbing and is known to have a commensal relationship with protozoa within the biofilms, which can act as protective reservoirs for the bacteria $[122,158,159]$. As such, it is important that treatments can penetrate the extracellular polymeric substance (EPS) matrix of the biofilm and persist in large premise plumbing systems [160,161]. Chlorine dioxide was shown to be most effective in reducing L. pneumophila levels in biofilms in copper piping, compared to chlorine, monochloramine, electro-chlorination, ozone, and copper-silver ionization, due to its longer residual activity and its ability to penetrate the biofilm [162]. However, the amoeba in the biofilm were resistant to all forms of treatment and L. pneumophila was able to regrow after short periods of non-treatment [162,163].

High nutrient content, such as iron, organic carbon, nitrogen, and phosphorous support the growth and persistence of L. pneumophila, but the bacteria are also resistant against nutrient 
depletion $[63,126,164,165]$. Similar to the bacteria's defense against oxidative stress, L. pneumophila can become VBNC when experiencing nutrient depletion [126]. It appears that L. pneumophila can survive and thrive in any conventional pipe material. However, the bacteria are most prolific in cast iron pipes and least productive in copper piping, with plastic piping as the middle ground [40,166]. Piping materials can be taken into consideration for new construction projects, but tend to be a cost-prohibitive remediation or preventative factor in existing structures. It is important to consider the type of water distribution system, location, and use before deciding on treatment or mitigation options.

The laboratory and in-field experiments described above have shown that eradicating L. pneumophila within the biofilm is challenging if not unrealistic, and periods of treatment neutralization can lead to legionellosis outbreaks. Therefore, it can be postulated that the prevention of legionellosis should focus on decreasing infectivity of L. pneumophila rather than eliminating the bacteria from premise plumbing. Utilizing the lifecycle and genetic information discussed in this review and the following replication and egression reviews to create an effective QMRA model for $L$. pneumophila within the drinking water system is a first step in targeting the reduction of the bacteria's virulence and preventing legionellosis outbreaks.

\subsection{The Effects of Genetic Knockdowns}

Genetic knockdown information, which affects L. pneumophila's ability to invade the host cell, was gleaned from the literature (Table 1). Data is only reported in this article if it is sufficient to use in a mechanistic uptake model, requiring that it: was reported in a peer-reviewed journal, had greater than three data points, was validated, had sufficient variation in the independent variable, applied to genes that are responsible for pathogenesis, and was comparable to the other data provided. There is a lack of macrophage studies with appropriate data available in the literature, due in large part to murine studies being inappropriate for this model. Data available in the literature are difficult to use in one comprehensive model as the authors utilize different methodologies, various timeframes and report the effectiveness of the genetic knockdown in different units (i.e., percentage reduction vs. log reduction). In many studies, the knockdown causes only a minor reduction, making log reduction a less intuitive form of communication. In this article, the units expressed in the original paper are reported as well as the degradation of uptake rate, the percentage of bacteria, which were incapable of invading the host cell after the knockdown as compared to the wild-type. It is recommended that future research reports its results in percentage reductions for modeling purposes.

Table 1. Effects of Genetic Knockdowns on the uptake of L. pneumophila into a phagocyte.

\begin{tabular}{lcccc}
\hline Gene & Host Cell & $\begin{array}{c}\text { Change in Uptake } \\
\text { Efficiency }\end{array}$ & $\begin{array}{c}\text { Degradation of } \\
\text { Uptake Rate }\end{array}$ & Process \\
\hline relA & A. castellanii & $30-40 \%$ & $30-40 \% * *$ & $\begin{array}{c}\text { The flagella subunit is not produced, causing } \\
\text { reduced anchoring to the host cell [167] }\end{array}$ \\
\hline pilE & U937 cells & $33.9 \%$ & $66.1 \%$ & Only the short pili is expressed in mutant [80] \\
\hline pilE & HeLa cells & $34.0 \%$ & $66.0 \%$ & Only the short pili is expressed in mutant [80] \\
\hline pilE & WI-26 VA4 & $48.7 \%$ & $51.3 \%$ & Only the short pili is expressed in mutant [80] \\
\hline pilE & A.polyphaga & $53.4 \%$ & $46.4 \%$ & Only the short pili is expressed in mutant [80] \\
\hline lqs A & A. castellanii & $20-35 \%$ & $20-35 \%$ & $\begin{array}{c}\text { Diffusible signaling molecule (LA-1) is not } \\
\text { produced during mutation [168] }\end{array}$ \\
\hline lqsS & A. castellanii & $40-65 \%$ & $40-65 \%$ & $\begin{array}{c}\text { Sensor kinase which recognizes LA-1 is not } \\
\text { produced during mutation [168] }\end{array}$ \\
\hline letA & A. castellanii & Log 3 CFU/L & $99.9 \%$ & The flagella is not produced in mutant [169] \\
\hline Mip & $\begin{array}{c}\text { NCI-H292 lung } \\
\text { epithelial cells }\end{array}$ & Log 2 CFU/L & $99 \%$ & $\begin{array}{c}\text { Mutant loses the inability to cross the } \\
\text { extracellular matrix [170] }\end{array}$ \\
\hline
\end{tabular}

* Expressed in units reported in the original literature. ${ }^{* *}$ Degradation of Uptake Rate refers to the percentage of bacteria that were unsuccessful in invading the host cell as compared to the wild-type. *** Refers to the percentage of cells immotile after the relA knockdown. 


\subsection{Postulated Modeling Framework}

While an operational modeling framework will require additional research to develop from the data and knowledge in this review, a preliminary one can be postulated. It is clear that the phagocytosis process is vital to appropriately modeling the lifecycle of L. pneumophila, and if an accurate prediction of the concentration is desired. Therefore, the phagocytosis process needs to be modeled as well as general L. pneumophila growth and persistence in biofilms. It is also clear that the genes that regulate protein secretion and phylogenic characteristics required for effective uptake drive the uptake into host cells. Since the self-induced uptake of L. pneumophila is a vital component of its lifecycle, the effects on these genes from environmental stressors must be modeled. Due to the uncertainty and variability of the effects from environmental stressors, as well as the lack of data conducive to modeling, these processes would be modeled best in a stochastic method. Stochastic methods will allow for the uncertainties and variabilities to be accounted for and used in the model estimates. A postulated modeling framework for uptake into the host cell, including human macrophages can be seen in Figure 1. The foundation of environmental quality impacts genetic knockdown, which, in turn, affects phylogenetic outcomes and results in uptake rate degradation. Therefore, the framework in Figure 1 will allow for a mechanistic model of uptake rates due to environmental stress.

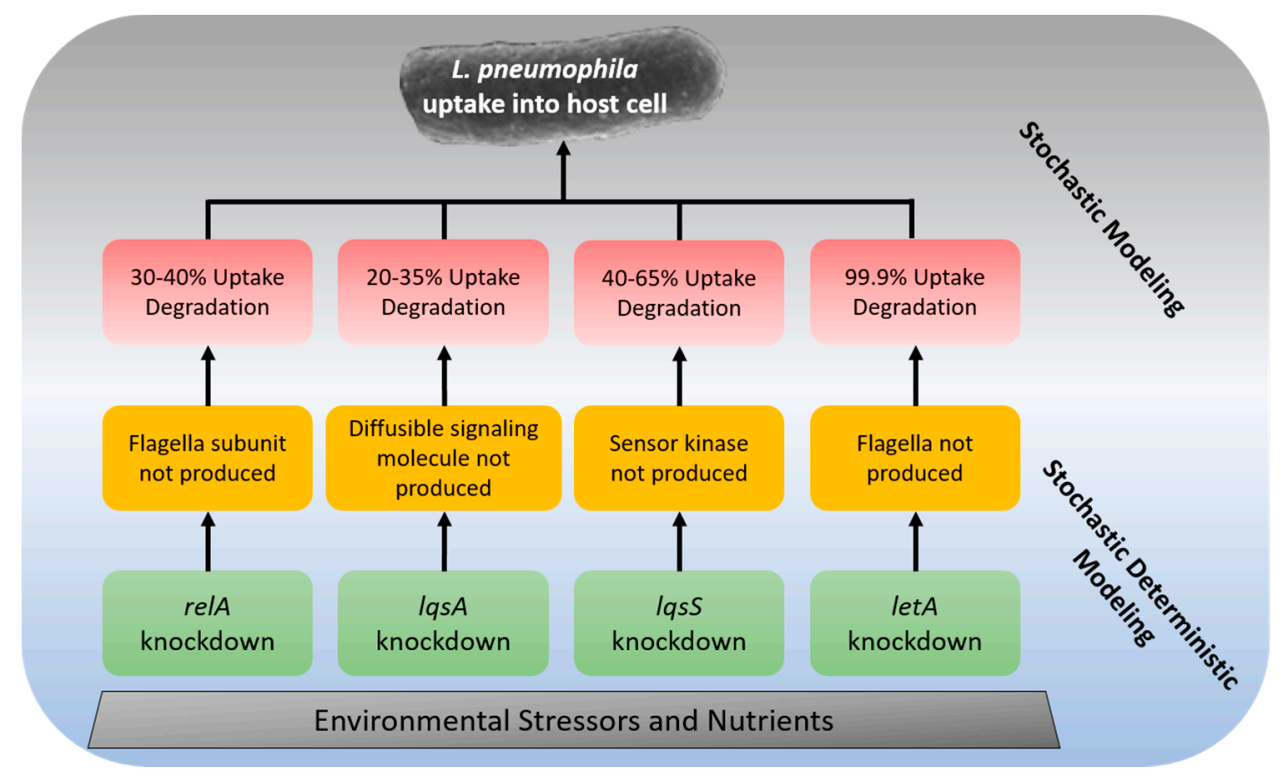

Figure 1. Postulated framework to computationally model the uptake of L. pneumophila into host cells.

\section{Discussion}

Legionellosis is a serious threat to human health and has been increasing in incidence throughout the US $[14,15]$. L. pneumophila thrive in warm, freshwater habitats, particularly where water is stagnant $[140,171]$. The pathogen prospers where industrial or residential hot water is kept under $50{ }^{\circ} \mathrm{C}[59,172]$. For these reasons, the premise plumbing of hospitals and hotels tend to be natural environments for the bacteria to live and proliferate. Unfortunately, the elderly and immunocompromised are at the highest risk for contracting LD, meaning L. pneumophila thriving within a hospital setting put the most vulnerable populations at higher risk. Furthermore, patients with ambulatory impediments may take longer to shower, causing a higher exposure time if L. pneumophila is present. Considering the rise in legionellosis incidence, numerous attempts have been made to eradicate L. pneumophila from water systems, in particular from biofilms of premise plumbing where the bacteria is significantly more difficult to treat than free living L. pneumophila. Prevention of the disease is difficult due to the endosymbiotic relationship L. pneumophila has with protozoa within the biofilm of premise plumbing systems [60]. 
L. pneumophila are particularly resistant to typical disinfection measures due to the ability to use protozoa as a reservoir [122]. There is a good deal of information regarding L. pneumophila's lifecycle and factors affecting the bacteria's virulence and persistence. However, a comprehensive literature review providing information necessary to model the behavior of L. pneumophila within a biofilm was not available, necessitating this article.

This literature review focuses on the uptake portion of the bacteria's lifecycle. While the role of many genes and gene complexes have been identified in the lifecycle of L. pneumophila, few studies have determined how environmental stressors (e.g., disinfectants), affects these genes [50]. Considering the prevalence of L. pneumophila in premise plumbing systems and the difficulty in eradicating the bacteria, reducing the infectivity of L. pneumophila may be a more productive solution than vain attempts of killing the bacteria. The most effective treatments of L. pneumophila in the premise plumbing system can be logistically challenging, if not prohibitive and costly. Additionally, repeated hyperchlorination events can have a negative impact on the plumbing system, which can lead to infrastructure concerns, other contaminants from the biofilm, and disinfectant byproducts [143]. Times of disinfectant neutralization have been shown to aid in the survival of the bacteria in the biofilm and decrease susceptibility to a disinfectant in the future [137]. Furthermore, L. pneumophila occupy a niche in the biofilm. Successfully eradicating the bacteria may allow for another pathogen to occupy the now vulnerable niche.

The mechanisms between L. pneumophila's entry into a protozoa and a human macrophage are similar, and the genetic knockdowns which prevent the bacteria from uptake into a protozoan often prevent invasion of a macrophage as well $[80,168]$. However, L. pneumophila has redundancies in the uptake pathway, which allows the bacteria more versatility $[77,84]$. L. pneumophila utilizes multiple pathways to invade host cells, including traditional phagocytosis, coiling phagocytosis and pinocytosis, and multiple receptor-mediated pathways [81-83].

Not only will L. pneumophila utilize different methods to infect different species of host, in many cases, the bacteria are capable of utilizing more than one method of invasion on the same host cell. Furthermore, L. pneumophila is unique in its ability to attract host cells and initiate invasion as part of its lifecycle [173]. Preventing L. pneumophila from entering any protozoa within the biofilm will prove difficult as a result, but doing so will also decrease, if not eliminate, L. pneumophila's virulence. Determining if genetic knockdowns that will decrease infectivity in L. pneumophila will occur during the water treatment process is a first step in controlling legionellosis outbreaks. The knowledge and data in this review provide a clearer picture of how disinfection strategies can govern uptake into a host cell. Reduced uptake may be a part of a new means in controlling infectivity. The first step is modeling these processes for which these data are a vital initial foray into this knowledge space [174-177].

Acknowledgments: Funding for this research is partially supported by The Quantitative Microbial Risk Assessment Interdisciplinary Instructional Institute supported by the National Institute of General Medical Sciences of the National Institutes of Health (NIH) under Award Number R25GM108593.

Author Contributions: Alexis L. Mraz and Mark H. Weir conceived and designed concepts for this paper; Alexis L. Mraz performed the literature review and research; Alexis L. Mraz wrote the paper.

Conflicts of Interest: The authors declare no conflict of interest.

\section{References}

1. Glick, T.H.; Gregg, M.B.; Berman, B.; Mallison, G.; Rhodes, W.W.; Kassanoff, I. Pontiac fever an epidemic of unknown etiology in a health department: I. Clinical and epidemiologic aspects. Am. J. Epidemiol. 1978, 107, 149-160. [CrossRef] [PubMed]

2. Kaufmann, A.F.; McDade, J.E.; Patton, C.M.; Bennett, J.V.; Skaliy, P.; Feeley, J.C.; Anderson, D.C.; Potter, M.E.; Newhouse, V.F.; Gregg, M.B.; et al. Pontiac Fever: Isolation of the Etiologic Agent (Legionella pneumophila) and Demonstration of its Mode of Transmission. Am. J. Epidemiol. 1981, 114, 337-347. [CrossRef] [PubMed] 
3. Fraser, D.W.; Tsai, T.R.; Orenstein, W.; Parkin, W.E.; Beecham, H.J.; Sharrar, R.G.; Harris, J.; Mallison, G.F.; Martin, S.M.; McDade, J.E.; et al. Legionnaires' disease. N. Engl. J. Med. 1977, 297, 1189-1197. [CrossRef] [PubMed]

4. Winn, W.C. Legionnaires disease: Historical perspective. Clin. Microbiol. Rev. 1988, 1, 60-81. [CrossRef] [PubMed]

5. McDade, J.E.; Shepard, C.C.; Fraser, D.W.; Tsai, T.R.; Redus, M.A.; Dowdle, W.R. Legionnaires' disease. N. Engl. J. Med. 1977, 297, 1197-1203. [CrossRef] [PubMed]

6. Boshuizen, H.C.; Neppelenbroek, S.E.; van Vliet, H.; Schellekens, J.F.; den Boer, J.W.; Peeters, M.F.; Conyn-van Spaendonck, M.A. Subclinical Legionella infection in workers near the source of a large outbreak of Legionnaires disease. J. Infect. Dis. 2001, 184, 515-518. [CrossRef] [PubMed]

7. Kirby, B.D.; Snyder, K.M.; Meyer, R.D.; Finegold, S.M. Legionnaires' disease: Clinical features of 24 cases. Ann. Intern. Med. 1978, 89, 297-309. [CrossRef] [PubMed]

8. Lattimer, G.L.; Rhodes, L.V.; Salventi, J.S.; Galgon, J.P.; Stonebraker, V.; Boley, S.; Haas, G. The Philadelphia epidemic of Legionnaire's disease: Clinical, pulmonary and serologic findings two years later. Ann. Intern. Med. 1979, 90, 522-526. [CrossRef] [PubMed]

9. Edelstein, P.H.; Meyer, R.D. Legionnaires' disease. Chest 1984, 85, 114-120. [CrossRef] [PubMed]

10. Marston, B.J.; Lipman, H.B.; Breiman, R.F. Surveillance for Legionnaires' disease: Risk factors for morbidity and mortality. Arch. Intern. Med. 1994, 154, 2417-2422. [CrossRef] [PubMed]

11. Matsunaga, K.; Klein, T.W.; Friedman, H.; Yamamoto, Y. Involvement of nicotinic acetylcholine receptors in suppression of antimicrobial activity and cytokine responses of alveolar macrophages to Legionella pneumophila infection by nicotine. J. Immunol. 2001, 167, 6518-6524. [CrossRef] [PubMed]

12. Straus, W.L.; Plouffe, J.F.; File, T.M.; Lipman, H.B.; Hackman, B.H.; Salstrom, S.J.; Benson, R.F.; Breiman, R.F. Risk factors for domestic acquisition of legionnaires disease. Ohio Legionnaires' Disease Group. Arch. Intern. Med. 1996, 156, 1685-1692. [CrossRef] [PubMed]

13. Office of the Surgeon General (US); Office on Smoking and Health (US). The Health Consequences of Smoking: A Report of the Surgeon General; Reports of the Surgeon General; U.S. Public Health Service: Atlanta, GA, USA, 2004.

14. Neil, K.; Berkelman, R. Increasing incidence of legionellosis in the United States, 1990-2005: Changing epidemiologic trends. Clin. Infect. Dis. 2008, 47, 591-599. [CrossRef] [PubMed]

15. Centers for Disease Control and Prevention (CDC). Legionellosis-United States, 2000-2009. MMWR Morb. Mortal. Wkly. Rep. 2011, 60, 1083-1086.

16. Choffnes, E.R.; Mack, A. Global Issues in Water, Sanitation, and Health: Workshop Summary; National Academies Press: Washington, DC, USA, 2009.

17. Yoder, J.; Roberts, V.; Craun, G.F.; Hill, V.; Hicks, L.; Alexander, N.T.; Radke, V.; Calderon, R.L.; Hlavsa, M.C.; Beach, M.J.; et al. Surveillance for waterborne disease and outbreaks associated with drinking water and water not intended for drinking-United States, 2005-2006. Morb. Mortal. Wkly. Rep. Surveill. Summ. 2008, 57, 39-62.

18. National Research Council (US) Committee on Drinking Water Contaminants. Review of Methods for Assessing Microbial Pathogens; National Academies Press (US): Washington, DC, USA, 1999.

19. US EPA. Contaminant Candidate List 3-CCL 3. Available online: https://www.epa.gov/ccl/contaminantcandidate-list-3-ccl-3 (accessed on 13 January 2017).

20. Craun, G.F.; Brunkard, J.M.; Yoder, J.S.; Roberts, V.A.; Carpenter, J.; Wade, T.; Calderon, R.L.; Roberts, J.M.; Beach, M.J.; Roy, S.L. Causes of Outbreaks Associated with Drinking Water in the United States from 1971 to 2006. Clin. Microbiol. Rev. 2010, 23, 507-528. [CrossRef] [PubMed]

21. Benin, A.L.; Benson, R.F.; Arnold, K.E.; Fiore, A.E.; Cook, P.G.; Williams, L.K.; Fields, B.; Besser, R.E. An outbreak of travel-associated Legionnaires disease and Pontiac fever: The need for enhanced surveillance of travel-associated legionellosis in the United States. J. Infect. Dis. 2002, 185, 237-243. [CrossRef] [PubMed]

22. Rose, J.B. Future health assessment and risk-management integration for infectious diseases and biological weapons for deployed U.S. Forces. In Strategies to Protect the Health of Deployed U.S. Forces: Assessing Health Risks to Deployed U.S. Forces; The National Academies Press: Washington, DC, USA, 2000; pp. 59-112.

23. Muder, R.R.; Victor, L.Y.; Woo, A.H. Mode of transmission of Legionella pneumophila: A critical review. Arch. Intern. Med. 1986, 146, 1607-1612. [CrossRef] [PubMed] 
24. Osterholm, M.T.; Chin, T.D.; Osborne, D.O.; Dull, H.B.; Dean, A.G.; Fraser, D.W.; Hayes, P.S.; Hall, W.N. A 1957 Outbreak of Legionnaires' disease associated with a meat packing plant. Am. J. Epidemiol. 1983, 117, 60-67. [CrossRef] [PubMed]

25. Mahoney, F.J.; Hoge, C.W.; Farley, T.A.; Barbaree, J.M.; Breiman, R.F.; Benson, R.F.; McFarland, L.M. Communitywide outbreak of Legionnaires' disease associated with a grocery store mist machine. J. Infect. Dis. 1992, 165, 736-739. [CrossRef] [PubMed]

26. Den Boer, J.; Yzerman, E.P.; Schellekens, J.; Lettinga, K.D.; Boshuizen, H.C.; Steenbergen, J.; Bosman, A.; Hof, S.; Vliet, H.; Peeters, M.F.; et al. A large outbreak of Legionnaires' disease at a flower show, the Netherlands, 1999. Emerg. Infect. Dis. 2002, 8, 37-43. [CrossRef] [PubMed]

27. Pastoris, M.C.; Ciceroni, L.; Monaco, R.L.; Goldoni, P.; Mentore, B.; Flego, G.; Cattani, L.; Ciarrocchi, S.; Pinto, A.; Visca, P. Molecular epidemiology of an outbreak of Legionnaires' disease associated with a cooling tower in Genova-Sestri Ponente, Italy. Eur. J. Clin. Microbiol. Infect. Dis. 1997, 16, 883-892. [CrossRef]

28. Brown, C.M.; Nuorti, P.J.; Breiman, R.F.; Hathcock, A.L.; Fields, B.S.; Lipman, H.B.; Llewellyn, G.C.; Hofmann, J.; Cetron, M. A community outbreak of Legionnaires' disease linked to hospital cooling towers: An epidemiological method to calculate dose of exposure. Int. J. Epidemiol. 1999, 28, 353-359. [CrossRef] [PubMed]

29. Bhopal, R.S.; Fallon, R.J.; Buist, E.C.; Black, R.J.; Urquhart, J.D. Proximity of the home to a cooling tower and risk of non-outbreak Legionnaires' disease. Br. Med. J. 1991, 302, 378-383. [CrossRef]

30. Schwarzenbach, R.P.; Egli, T.; Hofstetter, T.B.; von Gunten, U.; Wehrli, B. Global water pollution and human health. Annu. Rev. Environ. Resour. 2010, 35, 109-136. [CrossRef]

31. Dondero, T.J.; Rendtorff, R.C.; Mallison, G.F.; Weeks, R.M.; Levy, J.S.; Wong, E.W.; Schaffner, W. An outbreak of Legionnaires' disease associated with a contaminated air-conditioning cooling tower. N. Engl. J. Med. 1980, 302, 365-370. [CrossRef] [PubMed]

32. Berglund, B.; Brunekreef, B.; Knöppe, H.; Lindvall, T.; Maroni, M.; Mølhave, L.; Skov, P. Effects of indoor air pollution on human health. Indoor Air 1992, 2, 2-25. [CrossRef]

33. Armstrong, T.W.; Haas, C.N. Legionnaires' disease: Evaluation of a quantitative microbial risk assessment model. J. Water Health 2008, 6, 149-166. [CrossRef] [PubMed]

34. Jernigan, D.; Hofmann, J.; Cetron, M.; Nuorti, J.; Fields, B.; Benson, R.; Breiman, R.; Lipman, H.; Carter, R.; Genese, C.; et al. Outbreak of Legionnaires' disease among cruise ship passengers exposed to a contaminated whirlpool spa. Lancet 1996, 347, 494-499. [CrossRef]

35. Lück, P.C.; Leupold, I.; Hlawitschka, M.; Helbig, J.; Carmienke, I.; Jatzwauk, L.; Guderitz, T. Prevalence of Legionella species, serogroups, and monoclonal subgroups in hot water systems in south-eastern Germany. Zentralbl. Hyg. Umweltmed. Int. J. Hyg. Environ. Med. 1993, 193, 450-460.

36. Lück, P.; Lau, B.; Seidel, S.; Postl, U. Legionellae in dental units-a hygienic risk? Dtsch. Zahn Mund Kieferheilkd. Zentralbl. 1991, 80, 341-346.

37. Steele, T.W.; Lanser, J.; Sangster, N. Isolation of Legionella longbeachae serogroup 1 from potting mixes. Appl. Environ. Microbiol. 1990, 56, 49-53. [PubMed]

38. Van Heijnsbergen, E.; de Roda Husman, A.M.; Lodder, W.J.; Bouwknegt, M.; Docters van Leeuwen, A.E.; Bruin, J.P.; Euser, S.M.; den Boer, J.W.; Schalk, J.A.C. Viable Legionella pneumophila bacteria in natural soil and rainwater puddles. J. Appl. Microbiol. 2014, 117, 882-890. [CrossRef] [PubMed]

39. Van Heijnsbergen, E.; van Deursen, A.; Bouwknegt, M.; Bruin, J.P.; de Roda Husman, A.M.; Schalk, J.A.C. Presence and persistence of viable, clinically relevant Legionella pneumophila bacteria in garden soil in the Netherlands. Appl. Environ. Microbiol. 2016, 82, 5125-5131. [CrossRef] [PubMed]

40. Rogers, J.; Dowsett, A.; Dennis, P.; Lee, J.; Keevil, C. Influence of temperature and plumbing material selection on biofilm formation and growth of Legionella pneumophila in a model potable water system containing complex microbial flora. Appl. Environ. Microbiol. 1994, 60, 1585-1592. [PubMed]

41. Dennis, R. Legionnaires' disease-preventative maintenance. J. Inst. Hosp. Eng. 1988, 42, 14-15. [PubMed]

42. Dennis, P. Environmental Factors Affecting the Survival and Pathogenicity of Legionella pneumophila. Ph.D. Thesis, Open University, Hong Kong, China, 1986.

43. Gast, R.J.; Moran, D.M.; Dennett, M.R.; Wurtsbaugh, W.A.; Amaral-Zettler, L.A. Amoebae and Legionella pneumophila in saline environments. J. Water Health 2011, 9, 37-52. [CrossRef] [PubMed]

44. Barbaree, J.M.; Sanchez, A.; Sanden, G.N. Tolerance of Legionella species to sodium chloride. Curr. Microbiol. 1983, 9, 1-5. [CrossRef] 
45. Ohno, A.; Kato, N.; Yamada, K.; Yamaguchi, K. Factors influencing survival of Legionella pneumophila serotype 1 in hot spring water and tap water. Appl. Environ. Microbiol. 2003, 69, 2540-2547. [CrossRef] [PubMed]

46. Abdel-Nour, M.; Duncan, C.; Low, D.E.; Guyard, C. Biofilms: The stronghold of Legionella pneumophila. Int. J. Mol. Sci. 2013, 14, 21660-21675. [CrossRef] [PubMed]

47. Delgado-Viscogliosi, P.; Solignac, L.; Delattre, J.-M. Viability PCR, a culture-independent method for rapid and selective quantification of viable Legionella pneumophila cells in environmental water samples. Appl. Environ. Microbiol. 2009, 75, 3502-3512. [CrossRef] [PubMed]

48. Harb, O.S.; Gao, L.Y.; Abu Kwaik, Y. From protozoa to mammalian cells: A new paradigm in the life cycle of intracellular bacterial pathogens. Environ. Microbiol. 2000, 2, 251-265. [CrossRef] [PubMed]

49. De Felipe, K.S.; Pampou, S.; Jovanovic, O.S.; Pericone, C.D.; Ye, S.F.; Kalachikov, S.; Shuman, H.A. Evidence for acquisition of Legionella type IV secretion substrates via interdomain horizontal gene transfer. J. Bacteriol. 2005, 187, 7716-7726. [CrossRef] [PubMed]

50. Bodet, C.; Sahr, T.; Dupuy, M.; Buchrieser, C.; Héchard, Y. Legionella pneumophila transcriptional response to chlorine treatment. Water Res. 2012, 46, 808-816. [CrossRef] [PubMed]

51. Fields, B.S.; Benson, R.F.; Besser, R.E. Legionella and Legionnaires' disease: 25 years of investigation. Clin. Microbiol. Rev. 2002, 15, 506-526. [CrossRef] [PubMed]

52. Yu, V.L.; Plouffe, J.F.; Pastoris, M.C.; Stout, J.E.; Schousboe, M.; Widmer, A.; Summersgill, J.; File, T.; Heath, C.M.; Paterson, D.L.; et al. Distribution of Legionella species and serogroups isolated by culture in patients with sporadic community-acquired legionellosis: An international collaborative survey. J. Infect. Dis. 2002, 186, 127-128. [CrossRef] [PubMed]

53. Fang, G.; Yu, V.L.; Vickers, R.M. Disease due to the Legionellaceae (other than Legionella pneumophila): Historical, microbiological, clinical, and epidemiological review. Medicine 1989, 68, 116-132. [CrossRef] [PubMed]

54. O'Connor, B.A.; Carman, J.; Eckert, K.; Tucker, G.; Givney, R.; Cameron, S. Does using potting mix make you sick? Results from a Legionella longbeachae case-control study in South Australia. Epidemiol. Infect. 2007, 135, 34-39. [CrossRef] [PubMed]

55. Cazalet, C.; Gomez-Valero, L.; Rusniok, C.; Lomma, M.; Dervins-Ravault, D.; Newton, H.J.; Sansom, F.M.; Jarraud, S.; Zidane, N.; Ma, L.; et al. Analysis of the Legionella longbeachae genome and transcriptome uncovers unique strategies to cause Legionnaires' disease. PLoS Genet. 2010, 6, e1000851. [CrossRef] [PubMed]

56. Centers for Disease Control and Prevention (CDC). Legionnaires' disease associated with potting soil-California, Oregon, and Washington, May-June 2000. MMWR Morb. Mortal. Wkly. Rep. 2000, 49, 777-778.

57. Graham, F.; White, P.; Harte, D.; Kingham, S. Changing epidemiological trends of legionellosis in New Zealand, 1979-2009. Epidemiol. Infect. 2012, 140, 1481-1496. [CrossRef] [PubMed]

58. Fliermans, C.B.; Cherry, W.B.; Orrison, L.H.; Smith, S.J.; Tison, D.L.; Pope, D.H. Ecological distribution of Legionella pneumophila. Appl. Environ. Microbiol. 1981, 41, 9-16. [PubMed]

59. Blackburn, B.G.; Craun, G.F.; Yoder, J.S.; Hill, V.; Calderon, R.L.; Chen, N.; Lee, S.H.; Levy, D.A.; Beach, M.J. Surveillance for waterborne-disease outbreaks associated with drinking water-United States, 2001-2002. Morb. Mortal. Wkly. Rep. Surveill. Summ. 2004, 53, 23-45.

60. National Research Council (US) Committee. Ecology and evolution of waterborne pathogens and indicator organisms. In Indicators for Waterborne Pathogens; National Academies Press (US): Washington, DC, USA, 2004.

61. World Health Organization. Guide to Ship Sanitation, 3rd ed.; World Health Organization: Geneva, Switzerland, 2011.

62. Flemming, H.-C. Biofilms in drinking water systems-part I: Overview. Gas Wasserfach Wasser Abwasser 1998, 139, S65-S72.

63. Jjemba, P.K.; Johnson, W.; Bukhari, Z.; LeChevallier, M.W. Occurrence and control of Legionella in recycled water systems. Pathogens 2015, 4, 470-502. [CrossRef] [PubMed]

64. Lau, H.Y.; Ashbolt, N.J. The role of biofilms and protozoa in Legionella pathogenesis: Implications for drinking water. J. Appl. Microbiol. 2009, 107, 368-378. [CrossRef] [PubMed]

65. Carrington, C.B. Pathology of Legionnaires' disease. Ann. Intern. Med. 1979, 90, 496-499. [CrossRef] [PubMed] 
66. Balows, A.; Fraser, D.; Swartz, M.N.; Carrington, C.B.; Eickhoff, T.C.; Isenberg, H.D.; Ward, P.A.; Tsai, T.F.; Finn, D.R.; Pilkaytis, B.D.; et al. International symposium on Legionnaires' disease, 13-15 November 1978, Atlanta, Georgia. Ann. Intern. Med. 1979, 90, 489-714.

67. Swartz, M.N. Clinical aspects of Legionnaires' disease. Ann. Intern. Med. 1979, 90, 492-495. [CrossRef] [PubMed]

68. Isenberg, H.D. Microbiology of Legionnaires' disease bacterium. Ann. Intern. Med. 1979, 90, 499-502. [CrossRef]

69. Eickhoff, T.C. Epidemiology of Legionnaires' disease. Ann. Intern. Med. 1979, 90, 499-502. [CrossRef] [PubMed]

70. Hubber, A.; Roy, C.R. Modulation of host cell function by Legionella pneumophila type IV effectors. Annu. Rev. Cell Dev. Biol. 2010, 26, 261-283. [CrossRef] [PubMed]

71. Isberg, R.R.; O'Connor, T.; Heidtman, M. The Legionella pneumophila replication vacuole: Making a cozy niche inside host cells. Nat. Rev. Microbiol. 2009, 7, 13-24. [CrossRef] [PubMed]

72. Kim, B.R.; Anderson, J.E.; Mueller, S.A.; Gaines, W.A.; Kendall, A.M. Literature review-Efficacy of various disinfectants against Legionella in water systems. Water Res. 2002, 36, 4433-4444. [CrossRef]

73. Taylor, M.; Ross, K.; Bentham, R. Legionella, protozoa, and biofilms: Interactions within complex microbial systems. Microb. Ecol. 2009, 58, 538-547. [CrossRef] [PubMed]

74. Swanson, M.; Hammer, B. Legionella pneumophila pathogenesis: A fateful journey from amoebae to macrophages. Annu. Rev. Microbiol. 2000, 54, 567-613. [CrossRef] [PubMed]

75. Albert-Weissenberger, C.; Cazalet, C.; Buchrieser, C. Legionella pneumophila-A human pathogen that co-evolved with fresh water protozoa. Cell. Mol. Life Sci. CMLS 2007, 64, 432-448. [CrossRef] [PubMed]

76. Declerck, P.; Behets, J.; De Keersmaecker, B.; Ollevier, F. Receptor-mediated uptake of Legionella pneumophila by Acanthamoeba castellanii and Naegleria lovaniensis. J. Appl. Microbiol. 2007, 103, 2697-2703. [CrossRef] [PubMed]

77. Harb, O.S.; Venkataraman, C.; Haack, B.J.; Gao, L.Y.; Kwaik, Y.A. Heterogeneity in the attachment and uptake mechanisms of the Legionnaires' disease bacterium, Legionella pneumophila, by protozoan hosts. Appl. Environ. Microbiol. 1998, 64, 126-132. [PubMed]

78. Declerck, P.; Behets, J.; Delaedt, Y.; Margineanu, A.; Lammertyn, E.; Ollevier, F. Impact of non-Legionella bacteria on the uptake and intracellular replication of Legionella pneumophila in Acanthamoeba castellanii and Naegleria lovaniensis. Microb. Ecol. 2005, 50, 536-549. [CrossRef] [PubMed]

79. Amer, A.O. Modulation of caspases and their non-apoptotic functions by Legionella pneumophila. Cell. Microbiol. 2010, 12, 140-147. [CrossRef] [PubMed]

80. Stone, B.J.; Abu Kwaik, Y. Expression of multiple pili by Legionella pneumophila: Identification and characterization of a type IV pilin gene and its role in adherence to mammalian and protozoan cells. Infect. Immun. 1998, 66, 1768-1775. [PubMed]

81. Bozue, J.A.; Johnson, W. Interaction of Legionella pneumophila with Acanthamoeba castellanii: Uptake by coiling phagocytosis and inhibition of phagosome-lysosome fusion. Infect. Immun. 1996, 64, 668-673. [PubMed]

82. Horwitz, M.A. The Legionnaires' disease bacterium (Legionella pneumophila) inhibits phagosome-lysosome fusion in human monocytes. J. Exp. Med. 1983, 158, 2108-2126. [CrossRef] [PubMed]

83. Rittig, M.G.; Krause, A.; Häupl, T.; Schaible, U.E.; Modolell, M.; Kramer, M.D.; Lütjen-Drecoll, E.; Simon, M.M.; Burmester, G.R. Coiling phagocytosis is the preferential phagocytic mechanism for Borrelia burgdorferi. Infect. Immun. 1992, 60, 4205-4212. [PubMed]

84. Kwaik, Y.A.; Gao, L.-Y.; Stone, B.J.; Venkataraman, C.; Harb, O.S. Invasion of protozoa by Legionella pneumophila and its role in bacterial ecology and pathogenesis. Appl. Environ. Microbiol. 1998, 64, 3127-3133. [PubMed]

85. Clemens, D.L.; Horwitz, M.A. Membrane sorting during phagocytosis: Selective exclusion of major histocompatibility complex molecules but not complement receptor CR3 during conventional and coiling phagocytosis. J. Exp. Med. 1992, 175, 1317-1326. [CrossRef] [PubMed]

86. Steinert, M.; Ott, M.; Lück, P.C.; Tannich, E.; Hacker, J. Studies on the uptake and intracellular replication of Legionella pneumophila in protozoa and in macrophage-like cells. FEMS Microbiol. Ecol. 1994, 15, $299-307$. [CrossRef]

87. Mintz, C.S.; Arnold, P.I.; Johnson, W.; Schultz, D.R. Antibody-independent binding of complement component C1q by Legionella pneumophila. Infect. Immun. 1995, 63, 4939-4943. [PubMed]

88. Mintz, C.S.; Schultz, D.R.; Arnold, P.I.; Johnson, W. Legionella pneumophila lipopolysaccharide activates the classical complement pathway. Infect. Immun. 1992, 60, 2769-2776. [PubMed] 
89. Bellinger-Kawahara, C.; Horwitz, M. Legionella pneumophila fixes complement component C3 to its surface-demonstration by ELISA. In Program of the 1987 Annual Meeting of the American Society of Microbiology, Atlanta, GA, 1-6 March; American Society for Microbiology: Washington, DC, USA, 1987; pp. 1-6.

90. Cianciotto, N.P.; Fields, B.S. Legionella pneumophila mip gene potentiates intracellular infection of protozoa and human macrophages. Proc. Natl. Acad. Sci. USA 1992, 89, 5188-5191. [CrossRef] [PubMed]

91. Fields, B.S. The molecular ecology of Legionellae. Trends Microbiol. 1996, 4, 286-290. [CrossRef]

92. Cianciotto, N.P.; Eisenstein, B.I.; Mody, C.H.; Engleberg, N.C. A mutation in the mip gene results in an attenuation of Legionella pneumophila virulence. J. Infect. Dis. 1990, 162, 121-126. [CrossRef] [PubMed]

93. Cianciotto, N.P.; Eisenstein, B.I.; Mody, C.H.; Toews, G.B.; Engleberg, N.C. A Legionella pneumophila gene encoding a species-specific surface protein potentiates initiation of intracellular infection. Infect. Immun. 1989, 57, 1255-1262. [PubMed]

94. Ratcliff, R.M.; Lanser, J.A.; Manning, P.A.; Heuzenroeder, M.W. Sequence-based classification scheme for the genus Legionella targeting the mip Gene. J. Clin. Microbiol. 1998, 36, 1560-1567. [PubMed]

95. Fischer, G.; Bang, H.; Ludwig, B.; Mann, K.; Hacker, J. Mip protein of Legionella pneumophila exhibits peptidyl-prolyl-cis/trans isomerase (PPlase) activity. Mol. Microbiol. 1992, 6, 1375-1383. [CrossRef] [PubMed]

96. Lundemose, A.G.; Kay, J.E.; Pearce, J.H. Chlamydia trachomatis Mip-like protein has peptidyl-prolyl cis/trans isomerase activity that is inhibited by FK506 and rapamycin and is implicated in initiation of chlamydial infection. Mol. Microbiol. 1993, 7, 777-783. [CrossRef] [PubMed]

97. Moro, A.; Ruiz-Cabello, F.; Fernández-Cano, A.; Stock, R.P.; González, A. Secretion by Trypanosoma cruzi of a peptidyl-prolyl cis-trans isomerase involved in cell infection. EMBO J. 1995, 14, 2483-2490. [PubMed]

98. Wintermeyer, E.; Ludwig, B.; Steinert, M.; Schmidt, B.; Fischer, G.; Hacker, J. Influence of site specifically altered Mip proteins on intracellular survival of Legionella pneumophila in eukaryotic cells. Infect. Immun. 1995, 63, 4576-4583. [PubMed]

99. Helbig, J.H.; Kurtz, J.B.; Pastoris, M.C.; Pelaz, C.; Lück, P.C. Antigenic lipopolysaccharide components of Legionella pneumophila recognized by monoclonal antibodies: Possibilities and limitations for division of the species into serogroups. J. Clin. Microbiol. 1997, 35, 2841-2845. [PubMed]

100. Köhler, R.; Fanghänel, J.; König, B.; Lüneberg, E.; Frosch, M.; Rahfeld, J.-U.; Hilgenfeld, R.; Fischer, G.; Hacker, J.; Steinert, M. Biochemical and functional analyses of the Mip protein: Influence of the N-terminal half and of peptidylprolyl isomerase activity on the virulence of Legionella pneumophila. Infect. Immun. 2003, 71, 4389-4397. [CrossRef] [PubMed]

101. Wieland, H.; Faigle, M.; Lang, F.; Northoff, H.; Neumeister, B. Regulation of the Legionella mip-promotor during infection of human monocytes. FEMS Microbiol. Lett. 2002, 212, 127-132. [CrossRef] [PubMed]

102. Garduño, R.A.; Quinn, F.D.; Hoffman, P.S. HeLa cells as a model to study the invasiveness and biology of Legionella pneumophila. Can. J. Microbiol. 1998, 44, 430-440. [CrossRef] [PubMed]

103. Moffat, J.F.; Tompkins, L. A quantitative model of intracellular growth of Legionella pneumophila in Acanthamoeba castellanii. Infect. Immun. 1992, 60, 296-301. [PubMed]

104. Köhler, R.; Bubert, A.; Goebel, W.; Steinert, M.; Hacker, J.; Bubert, B. Expression and use of the green fluorescent protein as a reporter system in Legionella pneumophila. Mol. Gen. Genet. MGG 2000, 262, 1060-1069. [CrossRef] [PubMed]

105. Abu Kwaik, Y.; Venkataraman, C.; Harb, O.S.; Gao, L.-Y. Signal transduction in the protozoan host Hartmannella vermiformis upon attachment and invasion by Legionella micdadei. Appl. Environ. Microbiol. 1998, 64, 3134-3139. [PubMed]

106. Lucas, C.E.; Brown, E.; Fields, B.S. Type IV pili and type II secretion play a limited role in Legionella pneumophila biofilm colonization and retention. Microbiol. Read. Engl. 2006, 152, 3569-3573. [CrossRef] [PubMed]

107. Mampel, J.; Spirig, T.; Weber, S.S.; Haagensen, J.A.J.; Molin, S.; Hilbi, H. Planktonic replication is essential for biofilm formation by Legionella pneumophila in a complex medium under static and dynamic flow conditions. Appl. Environ. Microbiol. 2006, 72, 2885-2895. [CrossRef] [PubMed]

108. Berk, S.G.; Ting, R.S.; Turner, G.W.; Ashburn, R.J. Production of respirable vesicles containing live Legionella pneumophila cells by two Acanthamoeba spp. Appl. Environ. Microbiol. 1998, 64, 279-286. [PubMed]

109. Cao, Z.; Jefferson, D.M.; Panjwani, N. Role of Carbohydrate-mediated adherence in cytopathogenic mechanisms of Acanthamoeba. J. Biol. Chem. 1998, 273, 15838-15845. [CrossRef] [PubMed]

110. Hales, L.M.; Shuman, H.A. The Legionella pneumophila rpoS gene is required for growth within Acanthamoeba castellanii. J. Bacteriol. 1999, 181, 4879-4889. [PubMed] 
111. Gal-Mor, O.; Segal, G. The Legionella pneumophila GacA homolog (LetA) is involved in the regulation of icm virulence genes and is required for intracellular multiplication in Acanthamoeba castellanii. Microb. Pathog. 2003, 34, 187-194. [CrossRef]

112. Escoll, P.; Rolando, M.; Gomez-Valero, L.; Buchrieser, C. From Amoeba to Macrophages: Exploring the Molecular Mechanisms of Legionella pneumophila Infection in Both Hosts. Curr. Top. Microbiol. Immunol. 2013, 376, 1-34. [PubMed]

113. Cirillo, J.D.; Falkow, S.; Tompkins, L.S. Growth of Legionella pneumophila in Acanthamoeba castellanii enhances invasion. Infect. Immun. 1994, 62, 3254-3261. [PubMed]

114. Gomez-Valero, L.; Rusniok, C.; Buchrieser, C. Legionella pneumophila: Population genetics, phylogeny and genomics. Infect. Genet. Evol. 2009, 9, 727-739. [CrossRef] [PubMed]

115. Atlas, R.M. Legionella: From environmental habitats to disease pathology, detection and control. Environ. Microbiol. 1999, 1, 283-293. [CrossRef] [PubMed]

116. Berjeaud, J.-M.; Chevalier, S.; Schlusselhuber, M.; Portier, E.; Loiseau, C.; Aucher, W.; Lesouhaitier, O.; Verdon, J. Legionella pneumophila: The paradox of a highly sensitive opportunistic waterborne pathogen able to persist in the environment. Front. Microbiol. 2016, 7. [CrossRef] [PubMed]

117. Declerck, P. Biofilms: The environmental playground of Legionella pneumophila. Environ. Microbiol. 2010, 12, 557-566. [CrossRef] [PubMed]

118. Emtiazi, F.; Schwartz, T.; Marten, S.M.; Krolla-Sidenstein, P.; Obst, U. Investigation of natural biofilms formed during the production of drinking water from surface water embankment filtration. Water Res. 2004, 38, 1197-1206. [CrossRef] [PubMed]

119. Yu-sen, E.L.; Vidic, R.D.; Stout, J.E.; Victor, L.Y. Legionella in water distribution systems. Am. Water Works Assoc. J. 1998, 90, 112-121.

120. Haas, C.N. Disinfection. In Water Quality and Treatment, A Handbook of Community Water Supplies; Pontius, F., Ed.; McGraw Hill: New York, NY, USA, 1990.

121. Miyamoto, M.; Yamaguchi, Y.; Sasatu, M. Disinfectant effects of hot water, ultraviolet light, silver ions and chlorine on strains of Legionella and nontuberculous mycobacteria. Microbios 1999, 101, 7-13.

122. Kilvington, S.; Price, J. Survival of Legionella pneumophila within cysts of Acanthamoeba polyphaga following chlorine exposure. J. Appl. Bacteriol. 1990, 68, 519-525. [CrossRef] [PubMed]

123. European Working Group for Legionella Infections (EWGLI). ESGLI/EWGLI Technical Guidelines for the Investigation, Control and Prevention of Travel Associated Legionnaires' Disease; The European Commission: Brussels, Belgium, 2011.

124. Cooper, I.R.; Hanlon, G.W. Resistance of Legionella pneumophila serotype 1 biofilms to chlorine-based disinfection. J. Hosp. Infect. 2010, 74, 152-159. [CrossRef] [PubMed]

125. Gião, M.S.; Wilks, S.; Azevedo, N.F.; Vieira, M.J.; Keevil, C.W. Incorporation of natural uncultivable Legionella pneumophila into potable water biofilms provides a protective niche against chlorination stress. Biofouling 2009, 25, 345-351. [CrossRef] [PubMed]

126. Murga, R.; Forster, T.S.; Brown, E.; Pruckler, J.M.; Fields, B.S.; Donlan, R.M. Role of biofilms in the survival of Legionella pneumophila in a model potable-water system. Microbiology 2001, 147, 3121-3126. [CrossRef] [PubMed]

127. Allegra, S.; Berger, F.; Berthelot, P.; Grattard, F.; Pozzetto, B.; Riffard, S. Use of flow cytometry to monitor Legionella viability. Appl. Environ. Microbiol. 2008, 74, 7813-7816. [CrossRef] [PubMed]

128. Chang, C.-W.; Hwang, Y.-H.; Cheng, W.-Y.; Chang, C.-P. Effects of chlorination and heat disinfection on long-term starved Legionella pneumophila in warm water. J. Appl. Microbiol. 2007, 102, 1636-1644. [CrossRef] [PubMed]

129. Ramamurthy, T.; Ghosh, A.; Pazhani, G.P.; Shinoda, S. Current perspectives on viable but non-culturable (VBNC) pathogenic bacteria. Front. Public Health 2014, 2. [CrossRef] [PubMed]

130. Cook, K.L.; Bolster, C.H. Survival of Campylobacter jejuni and Escherichia coli in groundwater during prolonged starvation at low temperatures. J. Appl. Microbiol. 2007, 103, 573-583. [CrossRef] [PubMed]

131. Um, H.Y.; Kong, H.G.; Lee, H.J.; Choi, H.K.; Park, E.J.; Kim, S.T.; Murugiyan, S.; Chung, E.; Kang, K.Y.; Lee, S.-W. Altered gene expression and intracellular changes of the viable but nonculturable state in Ralstonia solanacearum by copper treatment. Plant Pathol. J. 2013, 29, 374-385. [CrossRef] [PubMed]

132. Alleron, L.; Khemiri, A.; Koubar, M.; Lacombe, C.; Coquet, L.; Cosette, P.; Jouenne, T.; Frere, J. VBNC Legionella pneumophila cells are still able to produce virulence proteins. Water Res. 2013, 47, 6606-6617. [CrossRef] [PubMed] 
133. Epalle, T.; Girardot, F.; Allegra, S.; Maurice-Blanc, C.; Garraud, O.; Riffard, S. Viable but not culturable forms of Legionella pneumophila generated after heat shock treatment are infectious for macrophage-like and alveolar epithelial cells after resuscitation on Acanthamoeba polyphaga. Microb. Ecol. 2015, 69, 215-224. [CrossRef] [PubMed]

134. Steinert, M.; Emödy, L.; Amann, R.; Hacker, J. Resuscitation of viable but nonculturable Legionella pneumophila Philadelphia JR32 by Acanthamoeba castellanii. Appl. Environ. Microbiol. 1997, 63, 2047-2053. [PubMed]

135. Casini, B.; Valentini, P.; Baggiani, A.; Torracca, F.; Frateschi, S.; Nelli, L.C.; Privitera, G. Molecular epidemiology of Legionella pneumophila serogroup 1 isolates following long-term chlorine dioxide treatment in a university hospital water system. J. Hosp. Infect. 2008, 69, 141-147. [CrossRef] [PubMed]

136. Långmark, J.; Storey, M.V.; Ashbolt, N.J.; Stenström, T.-A. Accumulation and fate of microorganisms and microspheres in biofilms formed in a pilot-scale water distribution system. Appl. Environ. Microbiol. 2005, 71, 706-712. [CrossRef] [PubMed]

137. Codony, F.; Morató, J.; Mas, J. Role of discontinuous chlorination on microbial production by drinking water biofilms. Water Res. 2005, 39, 1896-1906. [CrossRef] [PubMed]

138. De Beer, D.; Srinivasan, R.; Stewart, P.S. Direct measurement of chlorine penetration into biofilms during disinfection. Appl. Environ. Microbiol. 1994, 60, 4339-4344. [PubMed]

139. White, G.C. Handbook of chlorination for potable water, wastewater, cooling water, industrial processes, and swimming pools. In Handbook of Chlorination for Potable Water, Wastewater, Cooling Water, Industrial Processes, and Swimming Pools; Van Nostrand Reinhold: New York, NY, USA, 1972.

140. Kool, J.L.; Carpenter, J.C.; Fields, B.S. Effect of monochloramine disinfection of municipal drinking water on risk of nosocomial Legionnaires' disease. Lancet Lond. Engl. 1999, 353, 272-277. [CrossRef]

141. Chen, X.; Stewart, P.S. Chlorine penetration into artificial biofilm is limited by a reaction-diffusion interaction. Environ. Sci. Technol. 1996, 30, 2078-2083. [CrossRef]

142. LeChevallier, M.W.; Cawthon, C.D.; Lee, R.G. Inactivation of biofilm bacteria. Appl. Environ. Microbiol. 1988, 54, 2492-2499. [PubMed]

143. Shen, Y.; Huang, C.; Lin, J.; Wu, W.; Ashbolt, N.J.; Liu, W.-T.; Nguyen, T.H. Effect of disinfectant exposure on Legionella pneumophila associated with simulated drinking water biofilms: Release, inactivation, and infectivity. Environ. Sci. Technol. 2017, 51, 2087-2095. [CrossRef] [PubMed]

144. Williams, M.M.; Braun-Howland, E.B. Growth of Escherichia coli in model distribution system biofilms exposed to hypochlorous Acid or monochloramine. Appl. Environ. Microbiol. 2003, 69, 5463-5471. [CrossRef] [PubMed]

145. Chiao, T.-H.; Clancy, T.M.; Pinto, A.; Xi, C.; Raskin, L. Differential resistance of drinking water bacterial populations to monochloramine disinfection. Environ. Sci. Technol. 2014, 48, 4038-4047. [CrossRef] [PubMed]

146. Backer, H.; Hollowell, J. Use of iodine for water disinfection: Iodine toxicity and maximum recommended dose. Environ. Health Perspect. 2000, 108, 679-684. [CrossRef] [PubMed]

147. Cargill, K.L.; Pyle, B.H.; Sauer, R.L.; McFeters, G.A. Effects of culture conditions and biofilm formation on the iodine susceptibility of Legionella pneumophila. Can. J. Microbiol. 1992, 38, 423-429. [CrossRef] [PubMed]

148. Thomas, W.M.; Eccles, J.; Fricker, C. Laboratory observations of biocide efficiency against Legionella in model cooling tower systems. ASHRAE Trans. 1999, 105, 607-623.

149. Farooq, S.; Chian, E.; Engelbrecht, R. Basic concepts in disinfection with ozone. J. Water Pollut. Control Fed. 1977, 49, 1818-1831. [PubMed]

150. Hamelin, C. Production of single-and double-strand breaks in plasmid DNA by ozone. Int. J. Radiat. Oncol. Biol. Phys. 1985, 11, 253-257. [CrossRef]

151. Domingue, E.L.; Tyndall, R.; Mayberry, W.; Pancorbo, O. Effects of three oxidizing biocides on Legionella pneumophila serogroup 1. Appl. Environ. Microbiol. 1988, 54, 741-747. [PubMed]

152. McGrane, W. Ozone, a study of the effects of biocides on Legionella pneumophila. Ind. Water Treat. 1995, $27,28-32$.

153. Bartram, J. Legionella and the Prevention of Legionellosis; World Health Organization: Geneva, Switzerland, 2007.

154. Proctor, C.R.; Hammes, F. Drinking water microbiology-From measurement to management. Curr. Opin. Biotechnol. 2015, 33, 87-94. [CrossRef] [PubMed]

155. Murray, J. A study of the prevention of hot tapwater burns. Burns 1988, 14, 185-193. [CrossRef]

156. Boccia, S.; Laurenti, P.; Borella, P.; Moscato, U.; Capalbo, G.; Cambieri, A.; Amore, R.; Quaranta, G.; Boninti, F.; Orsini, M.; et al. Prospective 3-year surveillance for nosocomial and environmental Legionella pneumophila: Implications for infection control. Infect. Control Hosp. Epidemiol. 2006, 27, 459-465. [CrossRef] [PubMed] 
157. Dyck, A.; Exner, M.; Kramer, A. Experimental based experiences with the introduction of a water safety plan for a multi-located university clinic and its efficacy according to WHO recommendations. BMC Public Health 2007, 7, 34. [CrossRef] [PubMed]

158. King, C.H.; Shotts, E.B.; Wooley, R.E.; Porter, K.G. Survival of coliforms and bacterial pathogens within protozoa during chlorination. Appl. Environ. Microbiol. 1988, 54, 3023-3033. [PubMed]

159. Storey, M.; Ashbolt, N.; Stenström, T. Biofilms, thermophilic amoebae and Legionella pneumophila-A quantitative risk assessment for distributed water. Water Sci. Technol. 2004, 50, 77-82. [PubMed]

160. Szewzyk, U.; Szewzyk, R.; Manz, W.; Schleifer, K.-H. Microbiological safety of drinking water. Annu. Rev. Microbiol. 2000, 54, 81-127. [CrossRef] [PubMed]

161. Wimpenny, J.; Manz, W.; Szewzyk, U. Heterogeneity in biofilms. FEMS Microbiol. Rev. 2000, 24, 661-671. [CrossRef] [PubMed]

162. Thomas, V.; Bouchez, T.; Nicolas, V.; Robert, S.; Loret, J.F.; Lévi, Y. Amoebae in domestic water systems: Resistance to disinfection treatments and implication in Legionella persistence. J. Appl. Microbiol. 2004, 97, 950-963. [CrossRef] [PubMed]

163. Srinivasan, A.; Bova, G.; Ross, T.; Mackie, K.; Paquette, N.; Merz, W.; Perl, T.M. A 17-month evaluation of a chlorine dioxide water treatment system to control Legionella species in a hospital water supply. Infect. Control Hosp. Epidemiol. 2003, 24, 575-579. [CrossRef] [PubMed]

164. Cianciotto, N.P. Iron acquisition by Legionella pneumophila. BioMetals 2007, 20, 323-331. [CrossRef] [PubMed]

165. Orsi, N. The antimicrobial activity of lactoferrin: Current status and perspectives. BioMetals 2004, 17, $189-196$. [CrossRef] [PubMed]

166. Gagnon, G.A.; Rand, J.L.; O’Leary, K.C.; Rygel, A.C.; Chauret, C.; Andrews, R.C. Disinfectant efficacy of chlorite and chlorine dioxide in drinking water biofilms. Water Res. 2005, 39, 1809-1817. [CrossRef] [PubMed]

167. Zusman, T.; Gal-Mor, O.; Segal, G. Characterization of a Legionella pneumophila relA Insertion Mutant and Roles of RelA and RpoS in Virulence Gene Expression. J. Bacteriol. 2002, 184, 67-75. [CrossRef] [PubMed]

168. Tiaden, A.; Spirig, T.; Sahr, T.; Wälti, M.A.; Boucke, K.; Buchrieser, C.; Hilbi, H. The autoinducer synthase LqsA and putative sensor kinase LqsS regulate phagocyte interactions, extracellular filaments and a genomic island of Legionella pneumophila. Environ. Microbiol. 2010, 12, 1243-1259. [CrossRef] [PubMed]

169. Lynch, D.; Fieser, N.; Glöggler, K.; Forsbach-Birk, V.; Marre, R. The response regulator LetA regulates the stationary-phase stress response in Legionella pneumophila and is required for efficient infection of Acanthamoeba castellanii. FEMS Microbiol. Lett. 2003, 219, 241-248. [CrossRef]

170. Wagner, C.; Khan, A.S.; Kamphausen, T.; Schmausser, B.; Ünal, C.; Lorenz, U.; Fischer, G.; Hacker, J.; Steinert, M. Collagen binding protein Mip enables Legionella pneumophila to transmigrate through a barrier of NCI-H292 lung epithelial cells and extracellular matrix. Cell. Microbiol. 2007, 9, 450-462. [CrossRef] [PubMed]

171. Barbaree, J.M.; Fields, B.S.; Feeley, J.C.; Gorman, G.W.; Martin, W.T. Isolation of protozoa from water associated with a legionellosis outbreak and demonstration of intracellular multiplication of Legionella pneumophila. Appl. Environ. Microbiol. 1986, 51, 422-424. [PubMed]

172. Ashbolt, N.J. Microbial contamination of drinking water and disease outcomes in developing regions. Toxicology 2004, 198, 229-238. [CrossRef] [PubMed]

173. Shevchuk, O.; Jäger, J.; Steinert, M. Virulence properties of the Legionella pneumophila cell envelope. Front. Microbiol. 2011, 2. [CrossRef] [PubMed]

174. Ashbolt, N.J.; Schoen, M.E.; Soller, J.A.; Roser, D.J. Predicting pathogen risks to aid beach management: The real value of quantitative microbial risk assessment (QMRA). Water Res. 2010, 44, 4692-4703. [CrossRef] [PubMed]

175. Weir, M.H.; Razzolini, M.T.P.; Rose, J.B.; Masago, Y. Water reclamation redesign for reducing Cryptosporidium risks at a recreational spray park using stochastic models. Water Res. 2011, 45, 6505-6514. [CrossRef] [PubMed]

176. Rodriguez-Alvarez, M.S.; Weir, M.H.; Pope, J.M.; Seghezzo, L.; Rajal, V.B.; Salusso, M.M.; Moraña, L.B. Development of a relative risk model for drinking water regulation and design recommendations for a peri urban region of Argentina. Int. J. Hyg. Environ. Health 2015, 218, 627-638. [CrossRef] [PubMed]

177. Petterson, S. Application of a QMRA framework to inform selection of drinking water interventions in the developing context. Risk Anal. 2016, 36, 203-214. [CrossRef] [PubMed]

(C) 2018 by the authors. Licensee MDPI, Basel, Switzerland. This article is an open access article distributed under the terms and conditions of the Creative Commons Attribution (CC BY) license (http:/ / creativecommons.org/licenses/by/4.0/). 